\title{
ICT Utilization As Correlates Of Academic Performance Among Students With Visual Impairment In Lagos State, Nigeria
}

\author{
Edward O. Eguavoen \\ Kenneth Dike Library, University of Ibadan, Nigeria
}

doi: 10.19044/esj.2016.v12n13p205 URL:http://dx.doi.org/10.19044/esj.2016.v12n13p205

\begin{abstract}
Vision, an essential part of human existence plays vital roles in the life of an individual and any hindrance to vision resulting in total or partial loss of sight creates difficulties in understanding the world around such an individual. The problem associated with academic performance of students with visual impairment has a number of indicators which have not received adequate attention from researchers in special education. This study therefore, examined the relationship of information and communication technology (ICT) utilisation on academic performance of students with visual impairment in Lagos State. The objectives of the study were to identify ICT tools, level of ICT utilisation as well as their relationship to academic .performance among students with visual impairment. Using descriptive research design of correlational type, twenty eight students with visual impairment were selected using purposive sampling technique from two special schools located within Lagos state. A structured questionnaire was used to elicit information from the respondents and data obtained were analysed using descriptive statistics and Pearson product moment correlation statistics. Two research questions were raised while one hypothesis was generated and tested at 0.05 level of significance. The results indicated that there was significant relationship between information and communication technology utilisation and academic performance of students with visual impairment in Lagos state $(r=.536, \mathrm{P}<.05)$. Based on the findings of the study, it is recommended that schools should adopt appropriate ICT tools that will enhance academic performance of students with visual impairment and to include ICT training skills in the curriculum of special schools.
\end{abstract}

Keywords: Information and communication technology utilisation, Academic performance, Students with visual impairment 


\section{Introduction}

Vision being the ability to see or the area that an individual can see from a particular position is a pivot through which the individual appreciate his or her environment. It is an essential part of human existence as it plays vital roles in the life of an individual by enabling him or her to be aware of near and far objects. Thus any hindrance to vision results in total or partial loss of sight and places such person at a great disadvantage such that many of the concepts which sighted persons acquire easily have to be taught deliberately to individuals with visual impairment. $3 / 4$ of what we learn in life according to Adediran (2000) are acquired through the organ of sight while Keefer (2011) reporting the declaration of The American Optometric Association that because $80 \%$ of a child's learning relies on his vision acuity, early detection and treatment are needed. In his opinion, Smith (2007) submitted that the loss of vision affects the individual in significant ways limiting mobility, access to printed information and independent living, use of new technology such as Information and communication technology (ICT)

Information and communications technology - or technologies (ICT) is an umbrella term which involves the use of any communication device or application, encompassing: radio, television, cellular phones, computer and network hardware and software, satellite systems and so on, as well as the various services and applications associated with them, such as videoconferencing and distance learning. ICTs are often spoken of in a particular context, such as ICTs in education, health care, or libraries (Rouse, 2005). According to the European Commission (2006), the importance of ICTs lies less in the technology itself than in its ability to create greater access to information and communication in underserved populations. Many countries around the world have established organisations for the promotion of ICTs, because it is feared that unless less technologically advanced areas have a chance to catch up, the increasing technological advances in developed nations will only serve to exacerbate the already-existing economic gap between technological "have" and "have not" areas. Internationally, the United Nations actively promotes ICTs for Development as a means of bridging the digital divide.

Information and communication technology (ICT) is an important tool which enhances academic performance of all students especially students with visual impairment. It is a necessary condition for the development of the digital proficiency required of today's citizens, and, on a more basic level, must consist of the use of multimedia technologies to recuperate, evaluate, store, produce, present and exchange information. The expansion of new technologies has made the accessibility of computers to today's students possible. The popularisation of computers has translated to 
the presence of these resources in multiple contexts in students' lives at school and at home.

ICTs facilitate the learning of school subjects and basic skills needed for a meaningful living thereby contributing to the development of their immediate environment and the society at large. ICT has brought about a revolution in every walk of today's life. Particularly, it has become an integral part of education and its impact on teaching and learning is widely accepted. In Nigeria, although the economy is still largely based on lowtechnology, low-value industries, but there is an awareness in government quarters of the importance of ICT in the country's development. Since the advent of information and communication technology, the education sector has been transformed a lot in the use of ICT (Wittwer \& Senkbeil, 2008).

Students' use of this ICT tool has expanded to Internet, e-mail, chat, programming, graphics, spreadsheet, online shopping, online literature searching, and other educational materials. Students' gender, age and year of study have no significant effect on their computer use and attitudes (Wittwer \& Senkbeil, 2008). Most students use ICT for general purpose, that is, communication, word processing, entertainment, etc. rather than educational purpose. A range of special equipments are available to help students with visual impairment gain access to the curriculum. Some of these equipments are low technology, e.g. magnifiers and mechanical Braille's, but a range of high-technology options are also available that will enable students with visual impairment to be included fully in lessons and to gain access to the ICT-based resources that are increasingly becoming part of teaching and learning (Salisbury, 2008). Students with visual impairment are not excluded from benefiting immensely from the opportunities presented by ICT to enhance their academic performance. However, the problem associated with academic performance of students with visual impairment in secondary schools has a number of indicators which have not received adequate attention from researchers in the field of special education. One of these factors is ICT utilisation. This study sets to investigate the impact of ICT utilisation on academic performance of students with visual impairment in selected schools in Lagos state

\section{Literature review}

Visual impairment is vision loss of a person to such a degree as to qualify him/her for an additional support need through a significant limitation of visual capability resulting from either disease, trauma, or congenital or degenerative conditions that cannot be corrected by conventional means, such as refractive correction, medication, or surgery. (Arditi \& Rosenthal, 1998). This functional loss of vision is typically defined to manifest with: 
- $\quad$ best corrected visual acuity of less than 20/60, or significant central field defect,

- $\quad$ significant peripheral field defect including homonymous or heteronymous bilateral visual, field defect or generalized contraction or constriction of field, or

- $\quad$ reduced peak contrast sensitivity with either of the above conditions.

Visual impairment is the consequence of a functional loss of vision, rather than the eye disorder itself. Eye disorders which can lead to visual impairments can include retinal degeneration, albinism, cataracts, glaucoma, muscular problems that result in visual disturbances, corneal disorders, diabetic retinopathy, congenital disorders, and infection." Visual impairment can also be caused by brain and nerve disorders, in which case it is usually termed Cortical Visual Impairment (CVI).

Students with visual impairment are those who are educated through means other than vision. A visually challenged student may be blind or partially sighted. The blind are not able to learn through the channel of vision whereas the partially sighted though handicapped is able to use limited vision to acquire educational skills. The partially sighted child also suffers from serious defective vision after all medical and surgical treatment has been given and compensatory lenses have been provided (Adesina, 2001; Eniola, 2005). Nkangwung and Adeyemi (2004) described visual impairment as a term encompassing the totally blind and the partially seeing, indicating a significant visual problem, which even with correction, adversely affects the child's functioning and educational performance (Heward, 2004).

Visual impairment can affect an individual at any age or age of life. Olukotun (2003) noted that a person can acquire vision loss before birth, at birth or later in life. Dodds (1993) and Adebiyi (2004) stated that the sudden and entire loss of sight can be overwhelmingly distressing for the victim, as well as those close to him; and that it often takes longer for an individual who suddenly lost his sight to adjust psychologically and socially than one who has a congenital loss of vision.

Many children who have low vision or are blind learn to read and write by using the Braille system of raised dots that can be read by touch rather than sight. They may also use a special laptop computer that allows them to take notes in Braille and print in Braille or English. Sophisticated electronic devices can also convert print into a form that is readable by students with visual impairment. Some computers can scan printed text for a blind student and read it aloud by means of a synthetic voice. Most children with visual impairments have some functional vision and can often read by using large-print materials. (Repp \& Coutinho, 2008)

In Nigeria, children who have visual impairment (that is, are blind or have low vision) receive an education that is comparable to their sighted 
peers. Although the majority of the children are taught in special schools, a growing proportion--including those who are blind and are being integrated into regular schools with the support of itinerant teachers of students with visual impairments. For example, Jones (2008) stated that approximately 12 out of 1,000 children receive some form of special education because of visual impairments.

Further, approximately less than $20 \%$ of all Nigerian students who are visually impaired manage to gain entrance to universities. It can be assumed that those who then go on to a university represent a highly selective group because they have managed to do so despite their impairment and greater difficulty in accessing written information. There has been little empirical research on the situation of students with impairments on the university level. The only exception is the study by Meister (1998), who interviewed students with motor, visual, or auditory impairments at 15 German universities with regard to acceptance of the impairment by their families, social integration, compensatory behaviour, motivating or discouraging factors in the course of study, and social support from other students. The results showed that depending on the type and severity of the impairment, these students required two to five times as much time to learn the syllabus and to prepare and revise lectures than did their peers without impairments. Because of this extra effort, they also reported requiring more breaks and having less time for leisure activities.

Findings from numerous studies have shown a positive relationship between the use of information and communication technology and students academic performance. For example, in an Illinois blue collar rural community, mathematics achievement levels improved (computation and problem solving skills) as well as student interest among elementary and secondary students (Blume, 2001). Using a computer assisted instruction (CAI) program called Fundamental Mathematics, led to higher mathematics achievement for students in two elementary and one middle school in a large urban North Carolina school district (Brown, 2002). In another study (Judson \& Sawada, 2000) involving eighth grade student, mathematics achievement increased through the integration of math and science using inquiry-based data-generation technology (graphing calculators and probes).

Reichstetter (2002) reported a study by Idding, Ortmann and Pride (1999) that, reading comprehension and vocabulary development achievement levels showed improvement through coupling technology with multiple instructional strategies. In Texas, higher classroom technology integration was found to positively associate with Iowa Test of Basic Skills scores in vocabulary, reading and writing for elementary students (Christensen, Griffin \& Knezek, 2001). For kindergarten children, daily structured computer activities made a difference on the concept age for 
children in one classroom compared to free exploration and play activities on the computer in a traditional classroom (Grubb, 2000).

Studies and other reports exist that show a positive relationship between academic achievement in multiple content areas when technology has been incorporated into the curriculum. For example, Conyers, Kappel and Rooney (1999) found that reading and writing achievement showed a consistent upturn by using technology strategies. Writing scores increased due to keyboard composition activities and the spellchecking, cutting, and pasting tools that are a part of the software. Reading test scores improved due to technology-assisted diagnosis and instruction provided to students. Science and mathematics levels improved with the use of a video-disc curriculum (Windows on Science and Mathematics).

Kosakowski (1998) cites several studies where benefits of academic performance were related to technology implementation. For example, in a 1994 meta analysis, Kulik (as cited in Kosakowski, 1998,) found the use of technology in the drill and practice of basic skills to be highly effective, and the ten-year project of Apple Classrooms of Tomorrow, reported by Dwyer (as cited in Kosakowski, 1998), where gains were made in advanced skills of students.

A study by Paul, VanderZee, Rue and Swanson (1996) investigated the effects of the Accelerated Reader (AR) technology-based literacy program on attendance and standardized test scores at elementary, middle, and high schools. A comparative analysis of data revealed statistically significant evidence that, on virtually every subject test (including reading, writing, mathematics, science, and social studies), the majority of schools that owned AR performed better than socio-economically comparable nonAR schools. Gains in academic performance increased with the length of time schools owned AR. Findings suggested that AR has a positive effect on student academic performance, especially for socio-economically disadvantaged children in urban areas.

The Illinois State Board of Education partnered with two outside groups, the National Computational Science Alliance (NCSA) and the North Central Regional Technology in Education Center (NCRTEC), to provide staff development, along with technological software, hardware, and support, to improve sixth grade student performance in the areas of mathematics, science, and reading (Hatkin \& Taggart, 2001). The study involved schools with students of low socioeconomic status, high transfer rates, and large percentages special education. An evaluation of the project found confirming evidence that showed students achieved high academic standards.

A school district in Texas has nearly eliminated its achievement gap between advantaged and disadvantaged students (Duttweiler \& Madden, 2001) attributable partly to its integration of technology into the schools. A 
paper presented by Tuckman (2001) discussed how a technology-based course on study skills yielded significant differences in student grade point averages (GPA) for those taking the course compared to students not taking the course, especially among African Americans.

Fouts (2000) found in a review of several studies that achievement increased when computer use was combined with traditional instruction. In the Technology and Education Standards Issue Brief (1996), studies on the use of technology for classroom instruction point to a range of benefits, including increases in student achievement levels. Wenglinsky (1998) conducted a national study suggested by Education Week and inspired by concerns of Technology Counts regarding the relationship between academic achievement and the use of educational technology. Data were drawn from the 1996 National Assessment of Educational Progress (NAEP) in mathematics, consisting of national samples of 6,227 fourth graders and 7,146 eighth graders. The size of the relationship between the various positive uses of technology and academic achievement was substantial for eighth graders.

Software Publishers Association (1998) reported on 219 research reviews and reports on original research projects. The report concluded that a measurable gain in student achievement could be achieved when technology is used as a learning tool. In a meta analysis of over 700 empirical research studies, Schacter (1999) reported that positive gains were observed in academic achievement with students who had access to:

(a) computer assisted instruction, or

(b) integrated learning systems technology, or

(c) simulations and software that teaches higher order thinking, or

(d) collaborative networked technologies, or

(e) design and programming technologies,...” (Schacter, p. 9)

No relationship between technology use and academic achievement was found in a small number of studies. The Wenglinsky (2003) findings were negligible for fourth graders. In a study by Kozlowski (2000), an Illinois district found that there was no guarantee that student achievement would improve based on the use of educational technology. Other factors were also relevant, such as changing the classroom/school ambience, working within an environment that was high-tech, and effective use of technology through applying appropriate tools. In almost all reports, no decrease in academic achievement occurred due to technology use. However, in one scenario, written tests administered on paper yielded lower scores for students accustomed to working with computers (Russell \& Haney, 2000). However, writing achievement showed a positive relationship to high classroom use of computers if writing was also tested using computers. Generally, computers constitute a common resource at school. The use of 
computers at school and in the classroom responds to two uses: as a source of information and as a system of support for teaching. As well, computer science is a subject studied at secondary school.

The computer is one of the technological resources many homes are equipped with. In the family home, the availability of the computer can respond to different purposes, in function with the type of users. Particularly, for students the computer represents a tool for work and plays an important role in entertainment. Via the internet, the computer constitutes a means of looking for and obtaining information, and is a means of communicating and participating in forums on a diverse number of topics.

In relation to performance, there is room to ponder different effects computer use by students could have depending on the context in which the use takes place. In the case of school, computer use would facilitate learning and therefore have a positive effect on performance. The educational activities that involve the use of technology capture the interest of students, which facilitates their understanding of the content and provides a different way of expressing knowledge. Empirical research on this subject shows evidence that confirms a relationship between computer use at school and academic performance. However, studies have not always been able to demonstrate a positive correlation between the use of computers at school and school performance. Antonijevic found in his study of data obtained from TIMSS, 2003 (Trends in International Mathematics and Science Study), which included 47 participant countries worldwide, that the use of computers in education contributes significantly to higher student performance in science but not in math. There was even negative correlation found between these two variables. The findings reflected in the literature on computer use at home are more consistent. Research has demonstrated a positive relationship between computer use at home and performance at school. The computer can be used to help with homework or for free-time activities. Even though excessive use of the computer as a means of entertainment can reduce personal time students dedicate to study outside of school, tasks such as looking for information online or communicating via the internet improve performance indirectly.

A search for information online involves the selection of adequate sources in order to extract, organize and integrate information: this type of task develops problem-solving skills in the subjects. Even the participation in chat rooms contributes to the development of these kinds of skills in greater measure than face to-face communication.

A study of British students, by Conole, de Laat, Dillon and Darby (2008), reveals that students are learning in a complex and changing environment, using a plethora of technological tools to support their learning. Such tools are worldwide considered powerful tools to foster learning 
(Hitchcock \& Stahl 2003) but, at the same time, it is well known that, due to the widespread use of technological tools, disadvantaged or excluded groups, including the unskilled, physically challenged and the elderly, face the danger of further marginalisation, in fact, with the advent of the digital computer, and its broad penetration, physically challenged and most especially students with visual impairment face serious problems in accessing computing devices (Stephanidis \& Savidis 2001).

A brief review of the e-learning tools that are widely used for educational purposes show some problems encountered by students with visual impairment in accessing and using e-learning materials. While affording the choice of the e-learning tools to be used in concrete educational settings by students with visual impairment, from one side, it is important to consider the nature, the specific features and the functionalities of the technological tools at hand; from the other side, it is necessary to take into account the actual, specific needs of the potential user/s (which are, of course, related to their impairments).

Students with visual impairment encounter different types of obstacles: in order to fully access the contents, in fact, the first category needs necessarily to rely on screen readers, while the second category, thanks to optical aids and/or to specific customisation options, may access a much wider variety of software applications, including those with graphic interface. Other significant differences can be found among the needs of the different categories of low vision students due to the wide variety of their visual impairments (Dini, Ferlino, Gettani, Martinoli \& Ott, 2006).

E-learning platforms often pose a number of different problems to students with visual impairment: small characters, crowded pages, pop up windows, iconic menus, complex forms to be filled in, etc. The availability of appropriate customising options could help to avoid such problems in order to enhance their academic performance. Educational software products are a very large category showing a wide number of different technical solutions; in the last years, GUI (Graphic User Interfaces) have been widely used and also the mouse has been often used as the only input system; recently international and national initiatives have produced significant changes in the direction of producing more accessible products even in this field.

It is difficult and maybe even impossible to imagine future learning environments that are not supported, in one way or another, by Information and Communication Technologies (ICT). When looking at the current widespread diffusion and use of ICT in modern societies, especially by the young - the so-called digital generation - then it should be clear that ICT will affect the complete learning process today and in the future. Both the Member States and the European Union have dedicated effort and resources 
to the promotion and implementation of ICT in education and training; and they continue to do so (e.g. the EU eLearning Programme2). It has also been acknowledged by the European Council held in Lisbon on 24 March 2000 that there is an urgent need to adapt European education and training systems according to the requirements of a knowledge-based society.

There is, in other words, a widespread belief that ICTs have an important role to play in changing and modernizing educational systems and ways of learning. There is, however, little scientific evidence of the concrete contributions of ICTs to the learning domain, despite the efforts of the last decades.

The impact of the ICT on learning can be approached in different ways. There is no single concept of learning through the use of ICT. Many different types can be envisaged: computer assisted learning, web-learning, computer-classes, online training, distance education, eLearning, virtual learning, digital training, etc. In this review, a broad view on ICT and learning is taken. Consequently, its impact on the learning process should encompass not only traditional learning outcomes but also the use of ICT by teachers (teacher training), the organisational use of ICT by education and training institutions, and, last but not least, the impact of ICT-enabled education on, for instance, personal development, confidence and self esteem.

This model could be useful for studying the impact of ICT-enabled education as it becomes increasingly difficult to isolate the specific educational use of ICT to determine its concrete impact. Educational achievements are not only shaped by the way education is organised but also by the socio-economic background of the learners and their socio-cultural environments, and by changing skills and competences required for employment, education and training, self-development and participation in society. This clarifies partly why non-formal learning, informal learning and adult learning are increasingly seen as crucial for the future of learning (Punie \& Cabrera, 2006).

Many different uses of ICT in education are possible. These range from using ICT as tools to support traditional ways of teaching to fully ICTenabled courses that entail a completely different way of teaching. Below is some evidence of the impact of ICT on educational achievements and on the way ICT is used in education. It throws light on the question of whether ICT should be a supplementary tool or an enabler of change and innovation.

The relationship with student performance in mathematics is striking. Students who have used computers for several years (37\% of the total sample for more than five years) mostly perform better than average. By contrast, those who do not have access to computers, or who have been using computers for only a short time, tend to lag behind their class year. The latter 
is influenced by their home backgrounds: students with low home access, in particular, are likely to come from disadvantaged backgrounds. However, even taking into account socioeconomic factors, a sizeable positive effect from regular computer use is evident. Students use computers at home for a wide range of functions, not just to play games. Half the students surveyed reported frequent use of word processing software and the Internet as a research tool (OECD, 2006). The ELNORD (2006) study also found that pupils at home use ICT for educational purposes, as a collaborative tool. They use e-mail, chat and mobile phones to communicate with classmates, giving and receiving help when doing their homework.

Studies in the Context of the E-Learning Initiative: it was found that ICT contributes greatly to both the teaching and the learning processes, and to knowledge-sharing, communication and home-school cooperation (ELNORD, 2006). The analysis of perception by headmasters, teachers, pupils and pupils' parents of the impact of ICT on learning shows a positive impact and beneficial consequences for the above mentioned actors and processes.

In the case of pupil performance, the areas where such an impact is most significant include subject-related performance and learning of basic skills such as reading and writing. ICT is seen positively by teachers as a valuable tool for tailoring learning, with beneficial effects on both academically strong and academically weak pupils. Nonetheless, avoiding exclusion is still an issue for example, not everyone enters schools with similar computer skills. More girls than boys learn all their computer skills at school. Also, disadvantaged immigrant students, whose first language is not the language of the country in which they live (i.e. a Nordic language in the case of the ELNORD study), depend more on schools to teach them computer skills.

ICT generally has a positive impact on learning but the expectations that ICT could in some ways revolutionise processes at school have not (yet) been realised. This goes beyond the use of computers by teachers since not only PCs and the internet but also digital cameras, mobile phones and other technologies can help to change teaching processes but clearly, ICT has not revolutionised teaching methods so far. The use of ICT is mostly focused on supporting the subject content. ICT-based activities by pupils are far more to do with consuming than producing. These work individually more often than together. However, the impact of integrating ICT in teaching can be measured in pupil engagement, differentiation and creativity and by the fact that less time is wasted, though the impact of ICT is very dependent on how it is used. Head headmasters typically view ICT as a valuable tool for pedagogical development but very few of them actually experience this impact (ELNORD, 2006). 


\section{Objectives}

The main objective of the study was to examine the relationship of ICT utilisation on academic performance among students with visual impairment in selected schools in Lagos state. Specifically the study sought to:

- $\quad$ identify types of ICT tools used by students with visual impairment in selected schools in Lagos state,

- $\quad$ determine the level of ICT utilisation by students with visual impairment in selected schools in Lagos state and

- $\quad$ determine the relationship between ICT utilisation and academic performance of students with visual impairment in selected schools in Lagos state.

\section{Research Questions}

1. What types of ICT tools are being used by students with visual impairment in selected schools in Lagos state?

2. What is the level of ICT utilisation of students with visual impairment in Lagos state?

\section{Hypothesis}

There will be no significant relationship between ICT utilisation and academic performance of students with visual impairment in Lagos state.

\section{Methodology}

The study adopted the correlational design of ex-post-facto to examine the relationship of ICT utilisation on academic performance of students with visual impairment in selected secondary schools in Lagos state, Nigeria. The population of the study consists of students with visual impairment in two secondary schools in Lagos state. The schools were Federal Government College, Ijanikin, Lagos state with 15 students with visual impairment and Queen's College, Lagos state with 13 students with visual impairment. Though there was difficulty in getting accurate data on the number of students with visual impairment in junior secondary schools from relevant government ministries, it was however evident from visits made to the schools that there are approximately twenty eight (28) students with visual impairment in JSS classes in the schools under study in Lagos state. The respondents were selected among students with visual impairment (totally blind) after screening them using Snellen chart to really ascertain their visual state in the selected schools and using enumerative sampling technique in selecting respondents for the study. The main instrument used for data collection is a structured questionnaire for the purpose of eliciting information from secondary school-going respondents who have visual 
impairment. The instrument is a standardized one which is made of three sections. Section A was aimed to elicit demographic information of the respondents, section B was for ICT utilisation while section C was for academic achievement respectively. The data collected in the study were analysed using descriptive statistics of mean score and standard deviation to answer research questions one and two while Pearson product moment correlation statistics was used to test the hypothesis formulated at 0.05 level of significance.

\section{Results}

The result of the findings is presented as follows:

Research question 1.

What type of ICT tools is available for use by students with visual impairment in Lagos state?

Respondents were asked to indicate using yes or no the type of ICT tools that they commonly use either at home or in school and the responses are summarized in table 1.

Table 1: Type of ICT tool used by students with visual impairment in Lagos state.

\begin{tabular}{|c|c|c|c|c|}
\hline Type of ICT Tool & Yes & $\%$ & No & $\%$ \\
\hline Personal computer & 9 & 32.1 & 19 & 67.9 \\
\hline Internet facility & 5 & 17.9 & 23 & 82.1 \\
\hline $\begin{array}{c}\text { E-learning } \\
\text { platforms }\end{array}$ & 3 & 11.7 & 25 & 89.3 \\
\hline $\begin{array}{c}\text { weblogs, social } \\
\text { networking sites, } \\
\text { podcasting }\end{array}$ & 7 & 25.0 & 21 & 75.0 \\
\hline e-mail & 12 & 42.9 & 16 & 57.1 \\
\hline Mobile phone & 22 & 78.6 & 6 & 21.4 \\
\hline Type of ICT Tool & Yes & $\%$ & No & $\%$ \\
\hline
\end{tabular}

It could be observed from the table that majority of respondents make use of mobile phones (78.6\%) while only a few (21.4\%) do not make use of mobile phones. Similarly, a greater percentage of respondents do not make use of personal computer as only about 31\% make use of personal computer. The table also revealed that only a few respondents (11.7) make use of elearning platforms. This shows that ICT tools which are likely to facilitate academic performance of students with visual impairment are either not available for them to use or not accessible. This is illustrated in figure 1. 


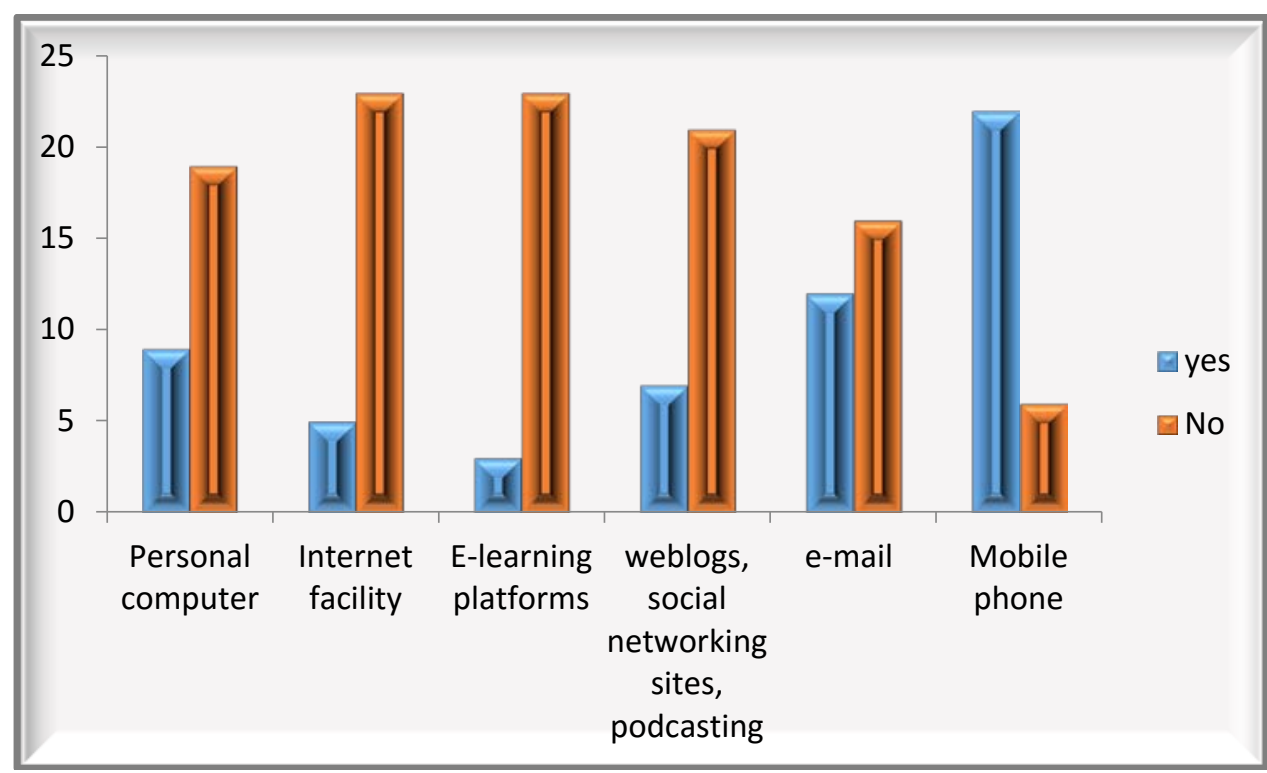

Figure 1: Chart showing ICT tools used by Students with visual impairment in Lagos state.

Research Question 2.

What is the level of ICT utilisation of students with visual impairment in Lagos state?

\begin{tabular}{|c|c|c|c|c|c|c|c|c|}
\hline \multirow{2}{*}{$\begin{array}{l}\text { Type of } \\
\text { ICT tool }\end{array}$} & \multicolumn{2}{|c|}{$\begin{array}{c}\text { Always } \\
\text { available }\end{array}$} & \multicolumn{2}{|c|}{ Available } & \multicolumn{2}{|c|}{ Not available } & \multirow[t]{2}{*}{ Mean } & \multirow[t]{2}{*}{ SD } \\
\hline & No. & $\%$ & No. & $\%$ & No. & $\%$ & & \\
\hline $\begin{array}{l}\text { Personal } \\
\text { computer }\end{array}$ & 6 & 21.4 & 9 & 32.1 & 13 & 46.4 & 1.82 & 0.88 \\
\hline $\begin{array}{c}\text { Internet } \\
\text { facility }\end{array}$ & 5 & 17.9 & 9 & 32.1 & 14 & 50.0 & 1.51 & 0.67 \\
\hline $\begin{array}{l}\text { E-learning } \\
\text { platforms }\end{array}$ & 3 & 10.7 & 6 & 21.4 & 19 & 67.9 & 0.98 & 0.69 \\
\hline $\begin{array}{l}\text { weblogs, } \\
\text { social } \\
\text { networking } \\
\text { sites, } \\
\text { podcasting }\end{array}$ & 12 & 42.9 & 9 & 32.1 & 7 & 25.0 & 2.17 & 0.56 \\
\hline e-mail & 12 & 42.9 & 8 & 28.6 & 10 & 35.7 & 2.11 & 0.55 \\
\hline $\begin{array}{l}\text { Mobile } \\
\text { phone }\end{array}$ & 19 & 67.9 & 7 & 25.0 & 2 & 7.1 & 2.88 & 0.37 \\
\hline \multicolumn{2}{|c|}{ Overall mean score } & \multicolumn{2}{|c|}{11.47} & & \multicolumn{2}{|c|}{ SD } & & 3.72 \\
\hline
\end{tabular}

The maximum score of the respondents' level of ICT use is 18. A score of $1-6$ indicates low level of ICT utilisation, 7-12 indicates moderate level of ICT utilisation, while 13-18 indicates high level of ICT utilisation. Table 2 indicated that the overall mean score of level of ICT utilisation being 
manifested by the students with visual impairment in Lagos state was ( $\mathrm{x}=$ 11.47; SD = 3.72) which falls within the range moderate level of ICT utilisation, it implies that the respondents elicit moderate level of ICT utilisation.

\section{Hypothesis}

There is no significant relationship between information and communication technology utilisation and academic performance of students with visual impairment in Lagos state, Nigeria.

Table 4.4: Relationship between information and communication technology utilisation and academic performance of students with visual impairment

\begin{tabular}{|c|c|c|c|c|c|c|}
\hline Variable & Mean & $\begin{array}{c}\text { Std. } \\
\text { Dev. }\end{array}$ & $\mathrm{N}$ & $\mathrm{R}$ & $\mathrm{P}$ & Remark \\
\hline $\begin{array}{c}\text { Academic } \\
\text { Performance }\end{array}$ & 24.5373 & 12.7853 & 28 & $.536^{*}$ & .000 & Sig. \\
$\begin{array}{c}\text { Information and } \\
\begin{array}{c}\text { Communication } \\
\text { Technology }\end{array}\end{array}$ & 61.9701 & 13.3598 & & & & \\
\hline
\end{tabular}

It is shown in the table that there was significant relationship between information and communication technology utilisation and academic performance of students with visual impairment .in Lagos state, Nigeria $(\mathrm{r}=$ $.536, \mathrm{P}<.05)$. The hypothesis which states that there is no significant relationship between information and communication technology utilisation and academic performance of students with visual impairment in Lagos state was therefore rejected. This means that there is a significant relationship between information and communication technology utilisation and academic performance of students with visual impairment in Lagos state, Nigeria.

\section{Discussion}

The result of the research question one indicated that the most prominent ICT tool used by students with visual impairment in Lagos state is mobile phones while only a fraction of them make use of e-learning platforms. This supports ELNORD (2006) who asserted that ICT is a valuable tool for pedagogical development but very few of them actually experience this impact. Similarly, the finding support Conole, de Laat., Dillon and Darby (2008) that students are learning in a complex and changing environment using a plethora of technological tools to support their learning.

Further, the result of research question two revealed that the level of usage of ICT tools by students with visual impairment is moderately low and this means that students with visual impairment do not use tools efficiently 
for academic purposes. This corroborates the findings of Hitchcock and Stahl, (2003) that due to the widespread use of technological tools, disadvantaged or excluded groups, including the unskilled, physically challenged and the elderly, face the danger of further marginalisation, in fact, with the advent of the digital computer and its broad penetration, the physically challenged as well as students with visual impairment face serious problems in accessing and using computing devices (Stephanidis \& Savidis, 2001).

The result of the hypothesis indicated that there is a significant relationship between academic performance and information and communication technology utilisation of students with visual impairment in Lagos state, Nigeria. This finding confirms earlier studies by Reichstetter (2002) and Idding, Ortmann and Pride (1999) that, reading comprehension and vocabulary development achievement levels showed improvement through coupling technology with multiple instructional strategies. It also supports that of Christensen, Griffin and Knezek, (2001) who equally found that higher classroom technology integration was found to positively associate with Iowa Test of Basic Skills scores on vocabulary, reading and writing for elementary students. With the proliferation of ICT platforms across the nation and in most high schools and or colleges, learners are now able to access needed information, harness it and apply the same to solving human challenges more readily with ease.

Further, the finding also supports that of Grubb (2000) who found a relationship between academic performance and ICT use. Studies and other reports exist that show a positive relationship between academic achievement in multiple content areas when technology has been incorporated into the curriculum. For example, Conyers, Kappel and Rooney (1999) found that reading and writing achievement tests showed a consistent upturn by using technology strategies. Writing scores increased due to keyboard composition activities and the spellchecking, cutting, and pasting tools that are a part of the software. Reading test scores improved due to technology-assisted diagnosis and instruction provided to students. Thus, the correlations either of achievement or of achievement-discrepancy scores, with measures of emotional stability or neuroticism, positive or negative self-concept, anxiety, aggression and introversion have earlier been confirmed (Worrell, 2007) while their direct linkage with academic potentialities with learners’ outcome were substantiated.

\section{Conclusion}

There are numerous benefits associated with the use of ICT by students with visual impairment; the most important of which is to enhance academic achievement as it is often a great challenge for them as they 
integrate themselves in getting to know and learn new things such as information and communication technology (ICT) tools to enhance their social and academic status. This usually affects their academic performance. This study has found correlations in the variable and academic performance and recommendations were made to better enhance the performance of students with visual impairment in junior secondary schools not only in Lagos state but the country at large.

\section{Recommendations}

The advent of ICT in educational system has revolutionalised the education sector and students with visual impairment are not left out as found in this study.

It is therefore recommended that schools should adopt appropriate ICT tools that will enhance academic performance of students with visual impairment.

Schools should also train students on proper usage of ICT tools to enhance their academic performance.

\section{References:}

Adebiyi, B.A. (2004). Effects of rational emotive behavioural and reality psychotherapies on socialisation of students with visual impairment in Federal College of Education (Special) Oyo, Nigeria. (Unpublished) Ph.D Thesis; Department of Special Education, University of Ibadan, pp. 1-12.

Adediran, D.A. (2000). Preparing the regular school teachers for the learning impaired children: an attempt at inclusive education. Footprints 1(1), pp. 12-16.

Adesina, S. (2001). Disabilities: a practical handbook for all people. Ilorin: Raja Dynamic Printers. pp. 2-5.

Arditi, A. and Rosenthal, B. (1998). Developing an objective definition of visual impairment. In Vision '96. Proceedings of the International Low Vision Conference. Madrid, Spain, pp. 331-333.

BECTA. (2000). Visual impairment and ICT. British Educational Communications and

Technology Agency. Coventry available at www.becta.org.uk/ science with technology. Unpublished Master's Thesis, Saint Xavier University, pp. 1-1

Brown, B. W. and Liedholm, C. Blume, J., Garcia, K., Mullinax, K. and Vogel, K. (2001). Integrating mathematics and E. Can web courses replace the classroom in principles of microeconomics? American Economic Review 92(2), pp. 444-448.

Charter of Fundamental Rights of the European Union. (2000). Official Journal of the European Union C. 364/01. 
Christensen, R., Griffin, D. and Knezek, G. (2001). Measures of teacher's stages of technology integration and their correlates with student achievement. ERIC Document Reproduction Service No.: ED451187.

Conole, G., de Laat, M., Dillon, T. and Darby, J. (2008). Disruptive technologies' pedagogical innovation: What's new? Findings from an indepth study of students' use and perception of technology. Computers \& Education 50(2), pp. 511-524.

Conyers, J.D., Kappel, T. and Roony, J. (1999). How technology can transform a school.

Educational Leadership 56(5), pp. 82-85.

Dini, S., Ferlino, L., Gettani, A., Martinoli, C. and Ott, M. (2006). Educational software and low vision students: evaluating accessibility factors, Universal Access in the Information Society, Springer Berlin, pp. 56. Dodds, A. (1993). Rehabilitating blind and visually impaired people: psychological approach. London: Chapman and Hall, pp. 3-7.

Duttweiler, P.C. and Madden, M. (2001). The district that does what's best for kids: special report on standards, assessment, accountability and inventions. National Dropout Prevention Centre. Clemson, SC

ELNORD. 2006. eLearning Nordic (2006). Available at www.ranbollmanagement.com.

Accessed on 9/9/2015.

Eniola, M.S. (2005). A comprehensive textbook of special education. Ibadan: Agbo Areo Publishers, pp. 3.

European Commission. (2006). The digital divide in Europe. Statistics in focus. European Commission: Luxembourg, pp. 7.

Fouts, J.T. (2000). Research on computers and education: past, present and future. Paper prepared for Bill and Melinda Gates Foundation. Seattle, WA, pp. 32-37.

Grubb, P. (2000). A comparison of concept age gains in kindergarten children in traditional and twenty-first century classrooms. Dissertations/Theses, pp. 69.

Hatkin, N. and Taggart, N. (2001). Gender, information technology and developing countries. The Learnlink Project. Washington: Academy for Educational Development, pp. 18 -23.

Heward, L.W. (2004). Exceptional children; an introduction to special education. $7^{\text {th }}$ ed.

Ohio; Merril Prentice Hall, pp.11.

Hitchcock, C. and Stahl, S. (2003). Assistive technology, universal design, universal design for learning: improved learning opportunities. Journal of Special Education Technology 18(4).

Iddings, S.A., Ortman, T.L., Pride, B. and Pride, H.L. (1999). Improving reading comprehension and vocabulary development through multiple 
instructional strategies and technology. Unpublished Master’s Thesis. St. Xavier University.

Keefer, A. (2011). Characteristics of a visually impaired child.United States: Pearson.

Kosakowski, J. (1998). The benefits of information technology. Clearing house on Information and Technology. Retrieved from the World Wide Web: http://www.ericit.org/index.

Kozlowski S.C. (2000). Better learning with technology. School Administrator 55, pp. 24-30.

Meister, J. J. (1998). Study behaviour, conditions and organisation in handicapped students. Munich, Germany.

Nkwangung, F.O. and Adeyemi, C.K. (2004). Instructional needs of children with visual impairment. Assessment and intervention strategies in special education. Ibadan: Glory-land Publishing Company, pp. 18

OECD. (2006). Are students ready for a technology-rich world? What PISA studies tell us. OECD: Paris. 22, pp. 1-9.

Olukotun, J.O. (2003). Teaching children with blindness and visual impairment: a basic text. Ibadan: Codat publications.

Paul, T., VanderZee, D., Rue, T. and Swanson, S. (1996). Impact of the accelerated reader tecnology-based literacy program on overall academic achievement and school attendance. Paper presented the National Reading Research Center Conference -Literacy and Technology for the 21st Century, Atlanta.

Punie, Y. and Cabrero, M. (2006). The future of ICT and learning in the knowledge society. Report on a Joint DG JRC/IPTS-DG EAC Workshop held in Sevilla, 20-21 October. Available at http://www.jrc.es Accessed on 15/2/2015.

Reichstetter, R. 2002. Literature review: technology use and its relevance to academic achievement. Available at http://www.wcpss.net/results/reports/2002/0246. Accessed on 16/9/2015.

Repp, A. C. and Coutinho, M. J. (2008). Special education. Microsoft ${ }^{\circledR}$ Encarta ${ }^{\circledR} 2009$ [DVD]. Redmond, WA: Microsoft Corporation.

Rouse, M. (2005). Definition of Information and Communications Technology. Available at www.whatis.com. Accessed on 09/04/2012.

Russell, M. and Haney, W. (2000). Bridging the gap between testing and technology in schools. Education Policy Analysis Archives 8.

Salisbury, R. (2008). Teaching pupils with a visual impairment: a guide to making the school curriculum accessible. David Fulton Publishers. Available from www.routledge.com/books. Accessed on 12/03/2014.

Scachter, S. (1999). Self-perception theory. New York. Academy of Science, pp. 9. 
Smith, D.D. (2007)). Introduction to special education; making a difference. $6^{\text {th }}$ ed. Boston: Pearson Education Inc.

Software Publishers Association. (1998). Report on the Effectiveness of technology in schools, 95-96. Washington, D.C.: Software Publishers Assn. Executive summary

URL http://www.spa.org/project/edu_pub/summary.htm, Accessed on 10/02/2012 Stephanidis, C. and Savidis, A. (2001). Universal access in the information society: methods, tools, and interaction technologies. Universal Access in the Information Society, Springer Berlin / Heidelberg, 1(1).

Technology and Education Standards. (1996). Issue Brief. National Governors’ Association, Washington, DC. pp. 1-8.

Tuckman, B.W. (2001). The strategies-for-achievement Approach (stACH) for teaching "study skills." 2001. Paper presented at the Annual Meeting of the American Research Association, Seattle, WA. pp. 11.

Wenglinsky, H. (1998). Does it Compute? The Relationship between educational technology and student achievement in mathematics. Princeton, NJ: Policy Information Center. Educational Testing Service [ETS], pp. 12.

Wittwer, J. and Senkbeil, S.A. (2008). Is student's computer use at home related their

mathematical performance at school? Computer. And Education 50, pp. 1558-1571.

Worrell, F.C. (2007). Ethnic identity, academic achievement, and global self-concept in four groups of academically talented adolescents. Gifted Child Q. 51(1), pp. 23-38. 